\title{
GHRL Gene
}

National Cancer Institute

\section{Source}

National Cancer Institute. GHRL Gene. NCI Thesaurus. Code C104427.

This gene is involved in regulating growth hormone release and satiety, thirst and anxiety. 